Paper presented at the 6th Topical Meeting on the Technology of Fusion Energy, San Francisco, CA, March 3-7, 1985; also for publication in Fusion Technology.

CONF-850310--78

DE85 010488

\title{
NEUTRONICS ACTIVITIES FOR NEXT GENERATION DEVICES*
}

\author{
Y. Gohar \\ Fusion Power Program \\ Argonne National Laboratory \\ Argonne, IL 60439
}

\section{DISCLAIMER}

This report was prepared as an account of work sponsored by an agency of the Unites States Government. Neither the United States Government nor any agency thereof, nor any of their employees, makes any warranty, express or implied, or assumes any legal liability or responsibility for the accuracy, completeness, or usefulness of any information, apparatus, product, or process disclosed, or represents that its use would not infringe privately owned rights. Reference berein to any specific commercial product, process, or service by trade name, trademark, manufacturer, or otherwise does not necessarily constitute or imply its endorsement, recommendation, or favoring by the United States Government or any agency thereof. The views and opinions of authors expressed hercin do not necessarily state or reflect those of the United States Government or any agency thereof.

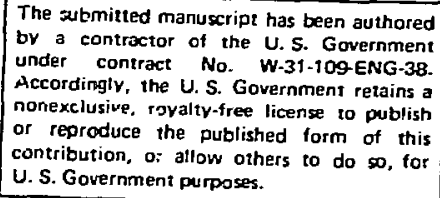


NEUTRONICS ACTIVITIES FOR NEXT GENERATIOA DEVICES

Y. Gohar

Fusion Power Program, Argonne Natlonal Laboratory

9700 South Cass Avenue

Argonne, IL 60439

(312) $972-4816$

\section{ABSTRACT}

Neutronics activitles for the next generation devices are the subject of this paper. The main activities include TFCX and FPD blanket/ shield studies, neutronice aspects of ETR/ INTOR critlcal 1seues, and neutronics cosputational modules for the cokamak system code and tandea wrror reactor ystea code. Trade-off analyses, optimization tudies, design problen Inveotigations and coaputational sodels developrent for reactor paresetric scudies carried out for these activities are sumarlzed.

\section{INTRODUCTION}

Parametric studles for TFCX were performed to define shlelding aterials, compositions, and thicknesses bssed on design requirementa, perforance and cost. The nuclear responses in the coroidal field (TF) colls and the dose equivalent one day after shutdow in the reactor hall are the indicators for the shielding perforance. Several shlelding materials were consldered in the enalys $1 s, e . g ., W$, steel, $\mathrm{TLH}_{2}, \mathrm{H}_{2} \mathrm{O}$, concrete, $\mathrm{Pb}$, and $\mathrm{B}_{4} \mathrm{C}$. Activation analysia and aflerheat of four design options were perforned for raste and aite atudiea. Hot upots in the TF colis due to neutrons and photons streanlng between the torus aegment were analyzed for the TFCX Inboard section. Design solutions vere laplesented to reduce the impact on the If colla.

FPD neutronies activitles concentrated on three areas: a) central cell blanket and shield crade-of studies to reduce the cepital cost, b) detalled analyals for the whole reactor to define the neutron leakage to the end cell, net tritlua breeing ratio, and enezgy deposition in the different reactor components, and c) end cell analyate to deteraine neutron il loading, heat deposition in the Cee colla, the uaxisun nuclear responses in the cee colls, and the perforance of ateel versus tungsten for cee coll shlelding at function of the thleld thlckness.
Three neutronics studies were performed for ETR/IATOR critical leaves. The chleld requirements and the bullding rall thicknesses for different design criterla with reupect to personnel access and arlutenance scensilo vere determined to aseas the lapact on the reactor capital cost for the ETR/INTOR eritiesl isoue D. The nucleonics aspects of the plasm stabilization elements for the transient electroagnetica ETR/INTOR critical 1asue $C$ vere analyzed. The radiation danage in the insulator aterials, the induced reafivity in the conductor aterials, and nuclear responses in these elewents vere astegsed as a function of the position relative to the first will. Neutronics aspects of two radlofrequency launchers were analyzed in detall to deteralne the replacenent frequency for the Beo wadow and the shlelding requiresents for ETR/IrTOR critical issue 8 .

Neutronics conputational wodules were developed for a tokanak reactor without critiun breeding blanket. The odels eatiace the perforance paraneter of two typea of shielda (oteel and tungeten) and the nuclear reaponses In the TF colls. The modules have been integrated into the tokamak syeteo code at IEDC and were used for TFCX etudy. For tander alror reactora, three conputational wdules vere developed for the central cell, the choke area, and the end cell. The central cell module predicts the perforance paranetere for self-cooled liquid netal (LI or 17L183Pb) blanketa and the requited shleld to protect the central cell colla and the workere in the reactor hell one day after hutdoun. The module calculate: blanket and ahield dimenclons, conposition and energy deposition in each sone of the central cell, tritiun breeding ratio, radiation responses in the central cell colle, and cost of each component. This wodule can be used in two codes: A) perfore the analyole for a opecific blenket and ohield design, or b) atnfalze, axtelze, or use -pecteic values for on or wre of unenteen blenket ens ahteld varlables to dafine tho blenket and hield configuration. The choke coll adule calculates the radiation respontes 
In the choke coll (noral copper and superconductor) and estiastes the ohleld requirements for the superconductor coll besed on the allowable nuclear reaponses. The end cell module has the sase functions as the choke coll for each cee coll and calculates the neutron wall loading distribution in the end cell.

This paper gives a sumary for each act 1vity including the key results and the main conclustons obtalned during the last flscal year.

\section{TFCX SHIELDING ANALYSES}

Design analyseg and tradeoff etudies vere perforwed for the bulk shield of the Tokamak Fusion Core Experioent (TFCX). Several shielding options re considerea to lower the capital cost of the ahielding yater. Optinization analyses we carried out to reduce the nuclear responses in the TF colla and the dose equivalent in the reactor hall one day after shutdown. Thls study was perforaed for two TFCX deaigns with different toroldal field coll configurations. The first design has superconductor colls to provide the required fleld on axis, designated superconducting design. The becond dealgn utillzes superconductor colls and noral copper insert colls located in the shield to produce the required fleld, designated hybrid dealgn.

\section{A. Inboard shield}

For the hybrid design with the steel shleld option, 1.e.. eteel/ $/ \mathrm{H}_{2} \mathrm{O} / \mathrm{B}_{4} \mathrm{C} / \mathrm{Pb}$, parawetric study was performed for the Inboard shleld to reduce the nuclear responses in the TF colls.1-3 The total thickness of the inboard shield $(t)$, thickness of the boton carbide zone $(x)$. thickness of the lead zone $(y)$, and water concentration in the steel zone (z) were varled. The aln objective is to deteralne the beat cosbination of values for $x$, $y$, and $z$ such that the maximus and the total nuclear heating in the faboard portion of the TF colls are animus for different $t$ values. Other nuclear responses, such as the maxinua dose in the ineulator material and the maxlmua faat neutron fluance in the winding material do not represent a concern for TFC because of the ohort operating tive of $2 \times 10^{5}$ seconds. However these responses behave similar to the nuclear heating with reapect to the coaposition and the thickness of the shleld. As an exauple of the reaulte of thie study, PIg. I give the maximun nuclear heating in the TP coll windins as a function of the wer concentration in the ateel ohield with lead zone thicknesses of 0,1 , and 2 ca. The toron carbide zone thicknesa 1 : $3 \mathrm{~cm}$ and the tocsl ahield thilcknase is $70 \mathrm{~cm}$. The boron carbide and the lead are lacated hetween the $I F$ coll and the eteel shield. The conclu-

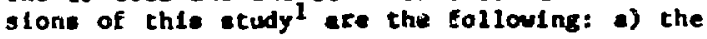

maximua nuclear heating in the IF coll winding 1. at a =inimu for a yater concentratico of around 202 in the eteel zone by volune; b) this infaun reaches the lovest value with 1 to $2 \mathrm{~cm}$ of boron carbide and $2 \mathrm{~cm}$ of lead; c) at this composition, the lowest nuclear heating in the TY coli, Hading and case, per unit length of the laboard aection is obtalned; and d) the elluination of the lead zone frow this conposition produces the lowest nuclear heating in the uinding aterial of the TP coll per unit length of the inboard section. However, the total nuclear heating in the TF coll 1s silght ly lacreased because wore photons reach the TP coll case. The last result 1s Important if two separate coolents wth different operating temferatures are used to cool the rinding and the case aeparately.

For the uperconducting design, three chlelding options vere considered for the inboard section of IFCX. The firat option is steel type shield which consists of 807 ateel. $20 z$ vater with 2 ca layer of boron carbide behind te based on che optimization ecudies perforwed for IMTOR. 4,5 For this option the ahield thickness was varied from 0 to 80 ca to analyze the radiation reaponae in the IF colls. The steel concentration was also varled from 60 to $90 \%$. The ahield wth $60 z$ aceel concentration represents aingle dianeter steels balls in a vater tank wich eliulnates the fabrication cost associated with the steel type shield.? P1g. 2 shows the aximue nuclear heating in the components of the laboard IP colls based on $1.8 \mathrm{mH} / \mathrm{a}^{2}$ DT neutron wall losiIng at the first wall and 60 ca total shield thickness. The increase in the water concencration from 20 to 402 by volume causea about a 357 increase in the totel nuclear heating in the IF coll and the maximure nuclear heating in the TF call unding anterials. Also, the radiation dose in the insulator aterialo increase by $\sim 40 \%$ for the sane change in the water concentration. The atonic dieplacement values in the copper stablitzer how siallar behavior to the dose in the innulator ateriala.

The second option 1s a tungaten type shleld which consista of $80 \mathrm{~W}, 10 \mathrm{z} \mathrm{H}_{2} \mathrm{O}$, and 102 steel. The otivation is to reduce the shield thickness required to achieve specific nuclear responses in the TP colis. As an example, two nuclear responses from the tungsten and the ateel options are shown in Figa. 3 and 4 assuning theoretical densities for all materialw. The results in these figures aze baed on separate celculatione for each shield thickness $(0,10,20,40$, and $60 \mathrm{~cm})$ ance the -tcenuation coefficient for the different nuclear responses are functions of the ohleld thickness. Compared to - 60 co ateel ahteld thickness, the tungaten option requtres only 45 to 48 ca to echleve the ase nuelear reaponese in che TF colla. This represente 


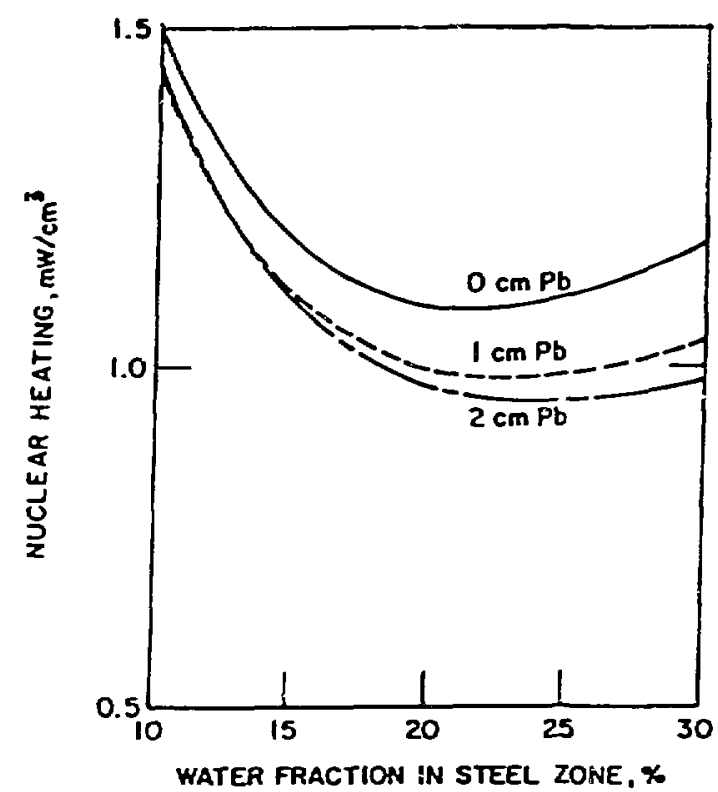

Fig. 1. Maximum nuclear heating in the IP coll winding as a Eunction of the water concentration in the steel shleld for different lead zone thicknesses, 70 co total ahield thicknees and 3-ca boron carbide zone thickness noralized to $1.8 \mathrm{~mW} / \mathrm{w}^{2}$ DT neutron wall loading at the first wali.

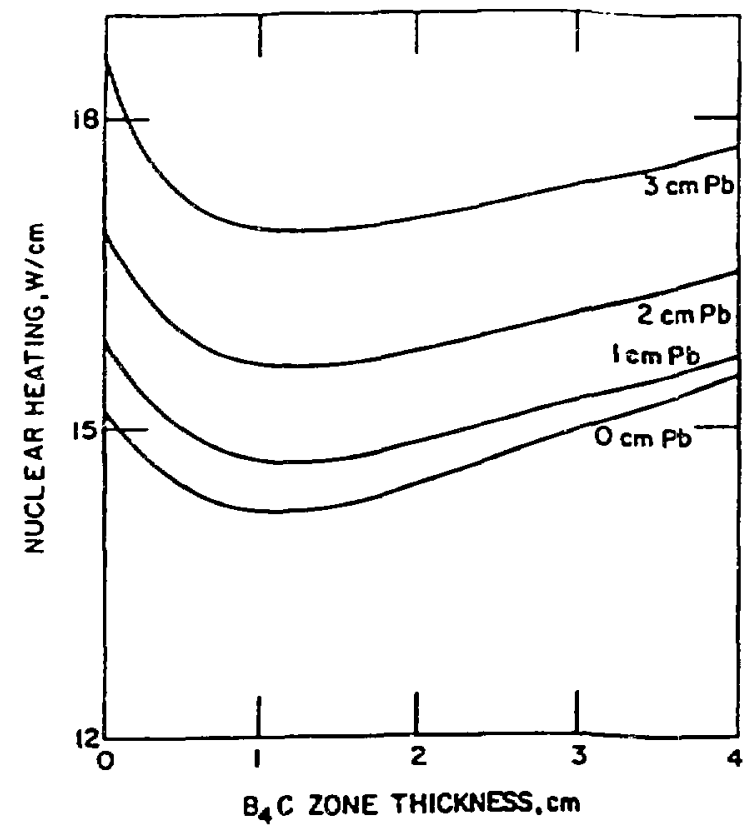

Fig. 2. Nuclear heating in the winding of the TP colla per unit length of the inboard section as function of the $B_{6} C$ zone thicknesa for different lead zone thickneases with $20 \mathrm{z}$ $\mathrm{H}_{2} \mathrm{O}$ in the steel hield and $70 \mathrm{~cm}$ total chlelt thickness noralized to $1.8 \mathrm{MW} / \mathrm{a}^{2}$ or neutron wall loading at the first wall.

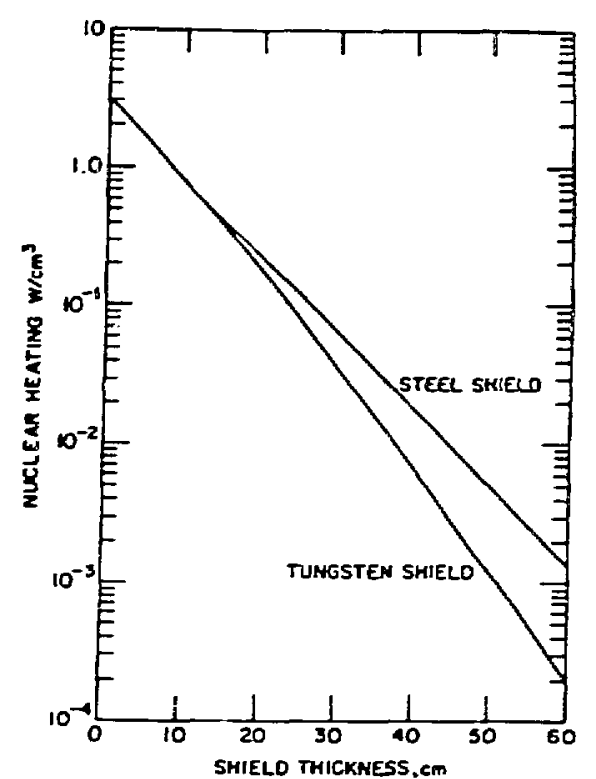

Fig. 3. Maximu nuclear heating in the IF coll uinding norallized to $1 \mathrm{~mW} / \mathrm{a}^{2}$ neutron uall loading.

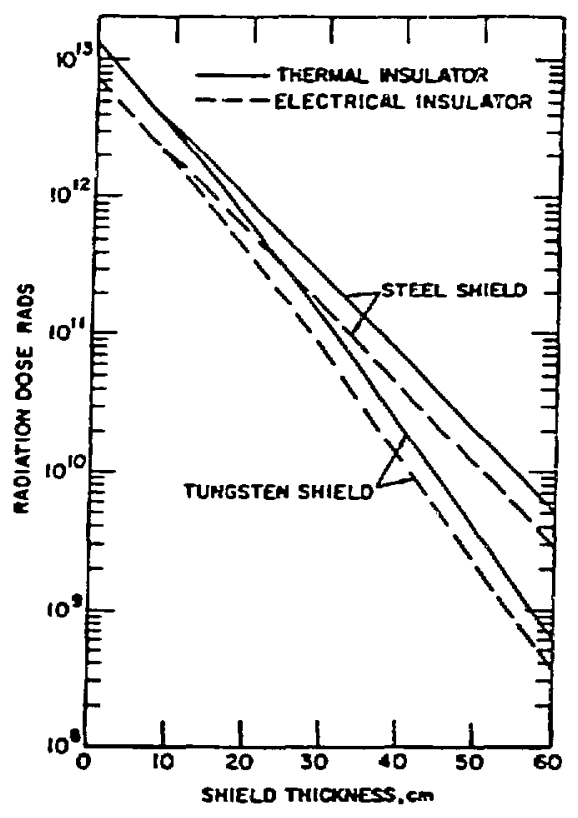

Fig. 4. Maxtaun radiation dose in the inaulator atertalo nomellzed to $1 \mathrm{ks} \cdot \mathrm{g}^{2}$ or neution fluence at the first wall. 
about 20 to $25 \%$ reduction in the Inboard shleld thickness for spectfic reaponses in TP colls. However, this reduction dialnishes as the ohield thickness becones saller. At a 20 co Inbont shieli thickness, the difference between both optlons is not worth antioning as shown in FIge. 3 and 4. Important factors In the conparison between the two opelons are the obtainable denalty and the high cost of the cungeten netal. For the sane shleld thickness, the cost of the tungaten option 18 - four times the steel. However, tungsten wetal $1 \mathrm{~s}$ the preferred option from the radloactivicy polnt of vieu. Al6o. it should be noted that the use of 1 to 2 cts of borun carbide between the tungaten shield and the TF coll reduces the nucleac heating in the winding materlal by a factor of 2 to 2.7 as the total shleld thickness changes from 25 to $75 \mathrm{cts}$.

The thlid option has the tungsten option wth a layer of hydrogeneous astertal $\left(\mathrm{H}_{2} \mathrm{O}\right.$ or $\mathrm{TtH}_{2}$ ) between the boron carbide and the tungsten shield to beniflt frow the high hydrogen content. The optimization analysis for this option gave the following conclualong: a) for the oane nuclest reaponses in the TF colls, this shield option reduces the required thickness by 4 to $9 \mathrm{~cm}$, relative to the second option; b) about 5 to $10 \mathrm{co}$ of a hydrogeneous layer $\left(\mathrm{H}_{2} \mathrm{O}\right.$ or $\left.\mathrm{T}_{2} \mathrm{H}_{2}\right)$ gives the lowest nuclear responses in the TF colls for a specific shield thickness; and c) the use of 1 to $2 \mathrm{ca}$ of boron carblde before the IF coll is beneflcial for this laprovenent. The largest Improvenent occurs in the fast neutron fluence and the copper atoulc displecerent. Sinllar results vere obtalned in the blanket and shlelding study of high power density tokanak reactor concepts.

\section{B. TFCX Outboard Shield}

The TFCX outboard shield dealgn is driven by the blological dose requiresents after shutdown and the radiation responses in the outboard cection of the TF colla. Several shteld options were analyzed with ewphasis on reducing the cost of the ohielding bystem by using low cost aterials.

The use of low cost aterials (water, concrete, etc.) require thicker shield to compensate for the difference in the attienuation characteriatics, relative to the steel shield. This leads to larger TF colls which Increase the cost of the angnet systen. In order to avold this altuation, the outboard shleld is divided to two sections. The firct section is designed to protect tise IF colls frow radiation dainge and excesalve nuclear heating. The second section 18 located between and outelde the $T$ collo to estisfy the dose criterion.

The steel belle concept is used for the
First section of the outboard shield to protect the $T$ colls. The aximun nuclear heatIng in the outer section of the $T P$ colls was calculated as anction of the chield thickness. About $70 \mathrm{co}$ of shield thickness is required to achieve about 1 eH/ch $\mathrm{cm}^{3}$ aximus nuclear heating in the IF colls.

Por the second section of the outboard shleld, three options are considered: a) wacer option, b) concrete option, and c) steel balls option. The analyses for these optlons rere carried out to deteraine the dose equivalent as a function of the shield thickness. Table 1 sumbarlzes the results based on 1 Hi.y/a 2 DT neutron wall at the first wall.

TABLE 1. TOTAL OUTBOARD SKIELD THICRNESS AS A TUMCTION OF THE DOSE CRITELION FOE THE OLFTEREKT SHIELO OPTIONS CALCILATED TOE $1 \mathrm{~m} \cdot \mathrm{y} / \mathrm{a}^{2}$ D-T MEUTEON IUUENCE AT THE TIRST VILL

\begin{tabular}{|c|c|c|}
\hline Shleld Opeton & $\begin{array}{l}\text { Shleld Th1ckneen } \\
\text { for } 2.5 \text { eree/h. }\end{array}$ & $\begin{array}{l}\text { Shield Thicknest } \\
\text { tor } 0.5 \text { erath. }\end{array}$ \\
\hline $\begin{array}{l}\text { Steel Balls } \\
\text { Steel Balls - Uater } \\
\text { Steel Ballo - Concrete }\end{array}$ & $\begin{array}{l}156 \\
190 \\
201\end{array}$ & $\begin{array}{l}168 \\
208 \\
221\end{array}$ \\
\hline
\end{tabular}

For $2 \times 10^{5}$ seconds of operation with 1.8 $M W / a^{2}$ DT neution loading, the required shield thickness in Iable 1 are reduced by 17 , 24, and $27 \mathrm{ce}$ for the steel balls, vater, and concrete option, respectively.

C. Hot Spots in the Inboard Section of the TPCX Toroldal Field Colle

The TPCX concepcual designe call for the conatruction of the reactor torus through the use of "ple-shaped seguents for nechanical and aintenance considerations. The use of this concept resulcs in hot spots in the 1nboard cection of the toroldal field (TP) colls due to neutrons and photons atreanting through the lota between the segrents. The enalysis wa performed to study the effect on the nuclear reaponses in the TP colls and introduce design soluelon, to reduce the Inpact on the reactor dealgn.

Two types of elots, atraight and single bend. ulth various widthe $(3,5$, and $7 \mathrm{ca})$ were considered. A aketch of the eiggle bend configuration with $3 \mathrm{co}$ udth is houn $1 \mathrm{a}$ Fig. 5. A volumetric neutron source located between $R-294$ co and 506 ce is uned to wodel the DT neutrone frow the plasen. The bulk ehield consteted of thongeneou atxture of 802 type 316 eteel and 202 water based on previous optinization scudies. A layer of boron carbide ahteld is located before the vacuus vessel to reduce the IT nuclear responses. The artigroup sonte carlo code MORSE was eaployed for the calculations. An isotropic diatcibution wa araned for the or 

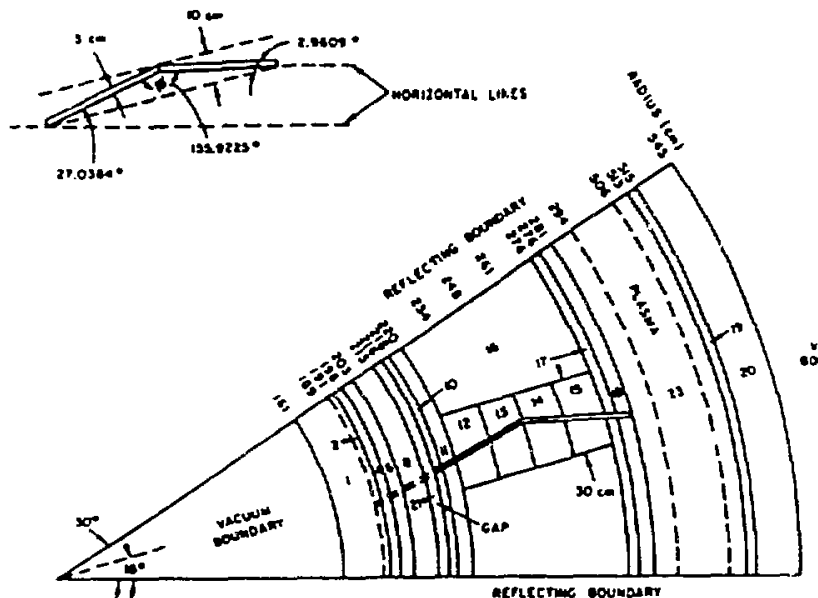

acrectriac noumoen

TABLE 2. NUCLEAR HEATIHG FACTORS IN THE TOROIDAL FIELD COIL

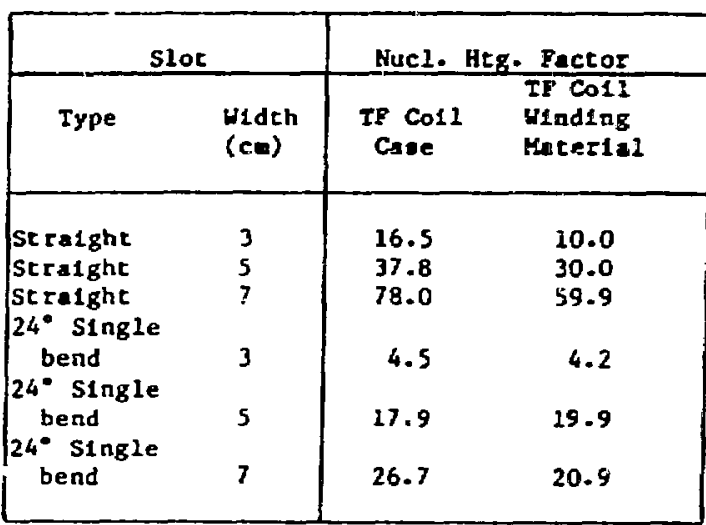

fig. 5. Sketch of the single-bend slot wodel.

neucrons with spatial blasing to increase the number of the DT neutrons generated near the slat ares. Geometric splitt!ng and Russion Roulette vere exployed to increase the probabllity of neutrons passing through the inboard shield and the extremely narrow slots. A 67 group ( 46 neutron and 21 gama groups) crose section set based on ENDF/B-IV was used in the calculations. Neutron and gamina kerma factors were included in the cross section set to generate the nuclear responses In the different reactor components. Nuclear heating results of these MORSE calculations relative to that of the no slot case usually used in the design process are given for the slot facing reglons in the TF case and the front $2 \mathrm{~cm}$ of the IF coll winding materials in Table 2. As expected, the nuclear heating increases as the slot width increases or the slot bending angle decreases. These small slous incresse the nuclear heating in the $T F$ case and winding naterials by one to two orders of magnitude which has atrong 1opact on TF coll design and perfornance. The $24^{\circ}$ single bend lot reduces the trearing effect by a factor of 2 to 4 for the case and the unding, respectively, relative to the stralght slot of the ane width. The nuclear heating can further be reduced by Incressing the bending angle, however, this will necessitate the use of wider lot to enable the radial replacement of the individual segment. Also, the nuclear heating in the sec$t$ ton of the $T F$ coll which does not face the slot increases by factors of 5,14 , and 26 relative to the no lot case for the three stralght slote of this study. This increase has a ignificant inpact on the refrigeration power requirements.

Th1s sudy denonatrates the otrong effect: of narroy lots on the IP colls and the effectivenese of bending the lot to reduce itu inpact on the design. The effect on other

- Nuclear heating factor 12 defined an the ratio between the axinu nuclear heating due to the slot divided by the noninal nucleat heating vithout lot in the ane reactor comonent.

nuclear reeponses such as radiation doeed in the insulating aterial, neutron fluence in the winding waterlais, and atomic displacement in the copper stabilizer are almilar to that of the nuclear heating.

\section{FPD BLANKET AND SHIELUING AMALYSES}

Neuctonica analyses for FPD- $I,-I I$, and -III (Fuslon Power Desonstration reactor) of the atrror progras were performed for the central cell, choke area, and the end cell. The central cell analysis includes a blenket optinization to reduce the capital cost, a shield design for the protection of the central cell colls, and blological shield design for the reactor room access one day after shutdown. The choke area analysis was carrled out to define the nuclear responses in the copper Insert coll and the euperconductor portion of the coll. Rigorous analysis was performed for the end cell since the capital cost of the end cell amounts to $\sim 602$ of the total capltal cost. An elaborate threedimensional (3-D) radiation transport analysis for the cesplete reactor systed was carrled out wich Includes the breeding blanket, the bulk shield, the central cell colls, the choke colls, the cee colls, and the blological *nieid. The general purpose Monte-carlo code MCNP was used for the calculations with a continuous energy representation for the nucleer crose sectlons based on ENDF/8-v nuclear data files. The energy spectrun and epatial distribution of the neutron source from the $D-T$ plagen in the central cell and the end cell were codeled explicity in the calculations. The cee coll reoserty vas modeled rigorouly sithout approximation by using the MIG code. 8 Reaults from the 3-D 
analyste include the net tritlus breeding rat 10, energy deposition in each cosponent of the reactor, radiation daage parameters in each coll, neutron leakage fros the central cell to the end cell and the detalled ahield desiga for the end cell.

\section{A. Central cell Analyzis}

The central cell analyale covers the following three sections: a) the tritius breeding blanket, b) the shlelding deaign to protect the central cell colls, and c) the biological shteld. In the design process for the three sections, the exphasis was to reduce the capital cost and the total weight of the central cell. The blanket is designed to convert the kinetic energy of the 0 r neutrons to recoverable heat and produce sdequate tritlua breeding to supply the triclua fuel requirement during the whole reactor lifetine as well as generate arplus of tritium to compensate for operating with non-breeding blanket eections or to atert another reactor wichin a reasonable period of tive. Econoulc and shlelding considerations require the blanket design to axinlze the recoverable heat produced which is defined as the energy deposited in the first wall, breeding zone, and reflector per fusion neutron. Neutronics analysis was perforaed to study the performance of the self-cooled naturel lithlunlead (17L183Pb) blanket concept. The inpact of the breeding zone thickness, reflector matertal selection, reflector composition, and reflector zone thlckness were enalyzed to deteralne the aln blanket paraneters. In the analyses, the flve kay paraweters considered to define the blenket for IPD are the capital cost, the cotal weight, the tritlus breeding rat1o, the energy deposition in the blanket per fuston neutron, and the energy loss to the shlelding systen. The analyols was performed for wide range for each key paraneter. Table 3 gives the central cell paraneters which resulted fron this analyols.

The shielding thickness for the central cell was deflned to schleve $0.1 \mathrm{mH} / \mathrm{ca}^{3}$ axiaun nuclear heating in the coll case. At this nuclear heating race, the capital cost for the central cell to animu based on the MFTP-a+T design anslysis. The devign criterion based on the nuclear heoting and the five year operating tiae (1007 avallablitty) produce low nuclear responses in the superconductor colls as shown in Table 3. The dealgn criterla for superconductor coll protection agalnat radiation is about two srders of agnitude higher than the values in Table 3.

\section{B. Choke cotl Analyels}

The choke coll analyals was pierforned to define the nuclest responses in bolth sections of the choke coll; the normal copper Insert and the superconductor. Based on the imclear responses siven in Tabla 3, the copper section can operate for 1.7 yeare (100z avallebllity) to reach $10^{13}$ rada in the ceranc ineuletor which is correapondting to 3 volz zuelling in the $\mathrm{KgAl}_{2} \mathrm{O}_{4}$. The cuperconductor section has an adequate $\mathrm{zg}$ In to operate for five year* (100z evallebilicy) without reach1ng any radiation darage dealgn liatt.

\section{End Cell Analyois}

An accurete 3-1 analyels was perforwed for the whole recctor to provide the following inforwation: a) the neutron sall loading in the end cell, b) the energy deposition in each coaponent, c) the net tritiun breeding ratio, d) the neutron leakage from the central cell to the end cell, and $e$ ) the hot spot polats in the cee colle. The 3-D geometrical wodel for the calculations 1a show in Fig. 6. The key resulte fron this enalysis are sumarized in thla section. The neutron wall loading in the end cell has $0.15 \mathrm{mH} / \mathrm{a}^{2}$ peak value at 2 \pm 46.1 whers $z$ 1s wasured frow the alddle of the central cell. The neutron wall loading detribution shows that the cee colls shield thickness can be tapered to leas than the 35 cll aterting fron $2= \pm 54=$. Table 4 gives tho energy deposition in each conponent per fuslon neutron and the statiatical error wthin one standard deviation. The energy deposition in the cee colls and the end cell blological chleld are 90.6 and $35.6 \mathrm{kw}$, reapectively. The shield thickness for the cee colls in the 3-D anslysis 1a $35 \mathrm{~cm}$. For the RPD design, it 1. posstble to use $45 \mathrm{co}$ of chield Inatend of 35 except for a feu spote, which reduces the energy deposition in the cee colls to about $26.4 \mathrm{kw}$. The point with inieun epace for hielding has an $8.6 \mathrm{w} / \mathrm{cm}^{3}$ aximun nuclear heating in the coll case $(1.5 \mathrm{co}$ coll case thickness and $1.5 \mathrm{ca}$ gap were assuaed in the 3-D analye1s) which can be accomodated in the Cee coll dealgn. The correaponding dose in the electrical ineulators 1o $1.1 \times 10^{10}$ rade per full powe: year.

IV. NEUTRONICS ASPECTS FOR ETR/INTOR CRITICAL ISSUES

\section{A. Persounel Access and Resoce Matntenance}

The INTOR shlelding ayated wa designed to achieve $2.5 \mathrm{area} / \mathrm{h}$ dose equivalent in the reactor hall one day after shutdown wit all chlelds in place. 4,5 This dose level peraits a hands-on ode of operation in the reactor hall. A seutronice ecudy was perforwed to define the shicld and the reactor bullding well thicknesses for three different configuratione. Two configurations periste per-onnel accese to the reactor hall one day after shutdow, and the third configuration ascunas ell-rewote melntenence. Tro dome aquivelent values are conoldered for the personnel accees configuratians, 2.5 and 0.5 wrea/h. The 2.5 prea/h raprasente the liatt for the oceupational exposure besed on worktne 
TABLE 3. EPD-I CENTRAL CELL AHD CHOKE COLL RARAMTERS

MaterLale

Central Cell Blanket Paraneter

Natural lithlum-lead (17L183Pb) breeder

Carbon reflector

Perricic ateel etructure

Dimenslone and Cosposition in the Neutronlce Model

First wall thickness (507 ferritic, 50217 (183Pb), cm

Breedet zone thickness ( $7.5 \mathrm{z}$ ferritic, $92.5 \mathrm{1}$ 17L183Pb), ca

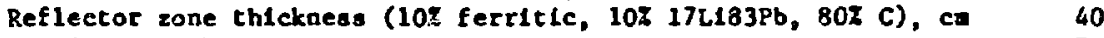

Breeding blanket length, a 70

Neutron rall loading, $\mathrm{kW} / \mathrm{m}^{2} \quad 1.95$

Perforwance Pararetera

Irfilum breeding ratio

Lithlua-6 enrichwent

Blanket energy oultiplication factor

Total energy wultplication factor (blanket and shleld)

Energy fraction deposited in the shield

1.37

$4.83 \times 10^{-2}$

Haterials

\section{Centrel Cell Shield}

Steel balls, water, $B_{4} C$ (powder), lead

Dimension and Composition Under the Colls Steel ahield (60Z Fel\$22 steel alloy, $\left.40 \pi \mathrm{H}_{2} \mathrm{O}\right)$, ca

Boron shield ( $42 \pi \mathrm{B}_{4} \mathrm{C}, 20 \mathrm{~T}$ Fel 422 steel alloy, $\left.202 \mathrm{H}_{2} \mathrm{O}\right), \mathrm{ct}$

45

Nuclear Responses is the Central Cell colls

Haximum nuclear heating in the coll case, wh/ $\mathrm{cm}^{3}$

Maximum nuclear heating in the winding. $\mathrm{m} / \mathrm{cm}^{3}$

Maxisua dose in the theral insulator, rado/Ha-y/m2

Maximua dose in the electrical ingulator, rads, MH.y/a

Maxinum dpa in the copper stablizer, dpa/thH.y/a 2

Pat neutron fluence ir. the winding aterial, $\mathrm{n} / \mathrm{cm}^{2} / \mathrm{H}^{\prime} \cdot \mathrm{y} / \mathrm{a}^{2}$

5

0.10

0.03

$3.53 \times 10^{7}$

$1.22 \times 10^{7}$

$3.44 \times 10^{-6}$

$4.54 \times 10^{15}$

Copper Insert

EPD-I Choke Co11

Neutron wall loading, $\mathrm{MH} / \mathrm{a}^{2}$

Maxlmum neulear leating in the coll case, $H / \mathrm{as}^{3}$

Maximus nuclear heariag in the copper coll, $H / \mathrm{cm}^{3}$

Maxiaun dose in the ceranic ingulator, rada/AH-y/a

Maxinum atomic displacement in the copper, dpa/MH-y/a

Superconductor

Neutron vall loading, $\mathrm{mW} / \mathrm{a}^{2}$

Mininum shielding thicknese, co

Maximun nuclear heating in the coll case, $\mathrm{m} / \mathrm{cm}^{3}$

Haxinue nuclear heating in the winding ateriala, aw/cm

Maximue dose in che invulator, rads/Mis:y/m

Maxinuw dose in the electricai inmulator, rade/M.y/m

Haxiaua fast neutron fluence in the unding aterlal, $\mathrm{n} / \mathrm{cm}^{2} / \mathrm{m} \cdot \mathrm{y} / \mathrm{o}^{2}$

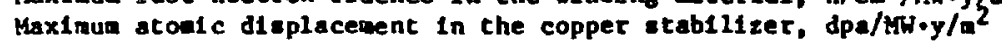

0.6

7.0

5.3

$6.1 \times 10^{12}$

6.8

0.8

70.0

0.46

0.16

$6.05 \times 10^{8}$

$2.53 \times 10^{8}$

$1.56 \times 10^{17}$

$1.96 \times 10^{-4}$

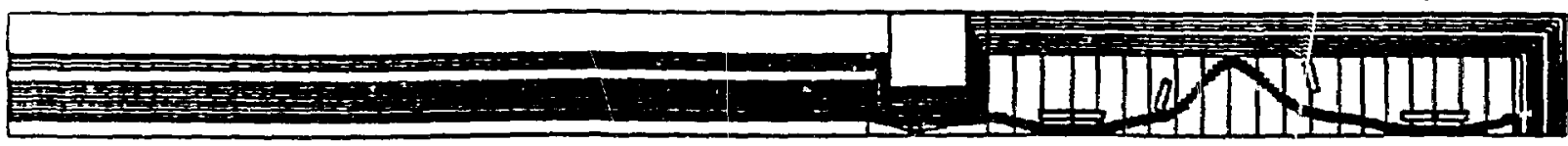

X - Z Plone

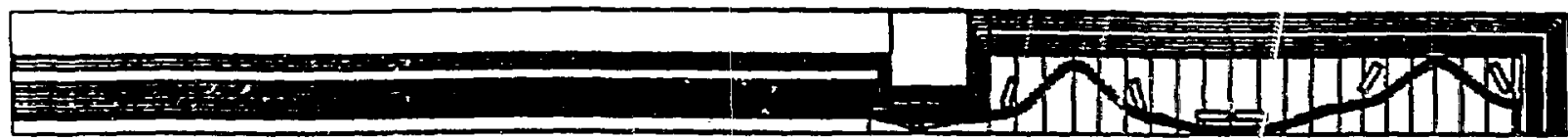

Y - Z Plane

1g. 6. Three dimensional geowericel sodel. 
TABLE 4. NUCLEAR HEATING AND POWER DISTRIBUTION Nuclear Heating Per Pusion Neutrin (Mev/DTn)

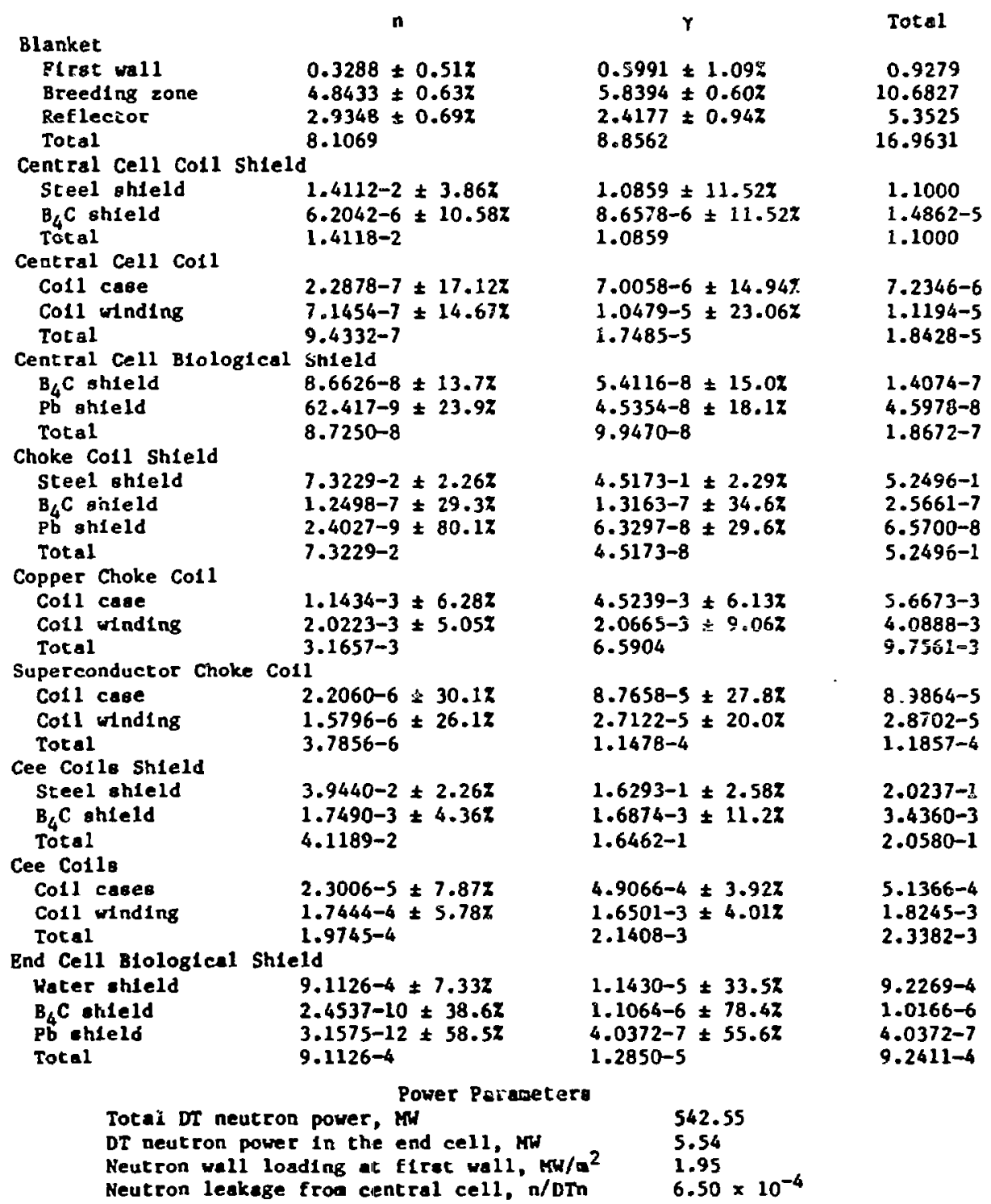

Power Distribution

Blanket

Central cell coll ahreld

Central cell coll

Central cell blological ohield

Choke coll hield

Copper choke coll

Superconductor choke coll

cee colls shield

Cee colls

End cell blologlcel ohield

MeV/DTn
16.96
1.10
$1.84-5$
$1.87-7$
$5.25-1$
$9.76-3$
$1.18-4$
$2.06-1$
$2.34-3$
$9.24-6$

Md

654.86

42.67

$7.10-4$

$7.22-6$

20.27

3.76-1

$4.56-3$

7.95

9.04-2

$3.56-2$ 
$8 \mathrm{~h}$ per day during the whole year. The 0.5 nrew/h satisfies the NhARA and DOE design guldeline for occupational exposure. The remote configuration design 1o based on providing adequate protection for the toroidal field colls without any conelderation for the dose equivalent in the reactor hall. For each configuration, the thickness of the reactor bullding wall was deeigned to attenuate the dose equivalent to $0.05 \mathrm{mren} / \mathrm{h}$ during operation. This dose level atisfles the proposed radiation dose guldeline in the "Clean Alr Act, Radiological Ealssion Standards," whlch requlres a $10 \mathrm{mrem} / \mathrm{y}$ on the site boundary.

Table 5 gives the ahlelding requirewents for the three conf1gurations. The key results from this study are the following: a) Por al1remote operation, the radloactivity concentretions in the reactor components outside the bulk shleld are incressed by four to five orders of magnitude conpered to the personnel access configurations, and b) only a sall difference in the overall cost of the reactor is obgerved among the different configurat lons.

TABLE 5. INTOR SHIELDING REQUIREMENTS FOR THE DIFFERENT CONFIGURATIONS

\begin{tabular}{|c|c|c|}
\hline $\begin{array}{c}\text { Shield Design } \\
\text { Criter1a }\end{array}$ & $\begin{array}{c}\text { Outboard Shield } \\
\text { Thickness, co }\end{array}$ & $\begin{array}{l}\text { wall Th1cknese } \\
\text { cd }\end{array}$ \\
\hline 0.5 mren/hr & 116 & 172 \\
2.5 mrea/h & 105 & 198 \\
All-rewote \\
operation
\end{tabular}

B. Nuclear Respenses in the Plasm Stabllization Element:

A etudy was cartied out to determine the nuclear responses in the plasea etabliliation elemente ast of the transient electroragnetica critical issue $C$ of EIR/INTOR act1vity. The main responses are rediation dose In the Inoulator aterial, induced realstivity and atomic dieplacesent in the condwctor material, neutron fluence, nuclear heating and life enelysis. In this study, both copper and a luminue conductore with elther $\mathrm{MgAl}_{2} \mathrm{O}_{4}$ or $\mathrm{MgO}$ Insulating aterial were inveatigeted.

The muclear reaponses in the atabllizethon elesents corresponding to the cases of $\mathrm{Cu}-\mathrm{MgAl}_{2} \mathrm{O}_{4}$, Cu-HgO, Al-Z(gAl $\mathrm{O}_{4}$, and $\mathrm{Al}-\mathrm{KgO}$ lead to the following concluafone:

1. There are easentially no changee in the calculated nuclear reaponaes when $\mathrm{HgO}$ L: substituted for $\mathrm{Kghl} \mathrm{O}_{2}$ a a Ineulating caterial for the sace conductor aterial.

2. The maximu Ineulator dose for the alund- nuv case to 1 to $10 \mathrm{z}$ aralier than for the copper case for both insulator.

3. The maximun neutron fluence ebove $0.1 \mathrm{keV}$ in the sluninua conductor is 6 to $7 \%$ less then In the copper conductor for both insulators.

4. The nuclear neating for the aluminus is 50-607 saller than for the copper case.

5. The maximua etoalc displecesent in the cluminum aterial is 10 to 302 higher than in the copper waterlal.

6. The copper resistivity at the end of life 111 Increase significanty $(\sim 477$ behind the first mil) due to atonic displecenent dange and nuclear transmutetions. The agnitude of the Increase 1s otrong fuaction of elenent poaltion relative to the first wall.

\section{Nuclear Responses and Shlelding Anelys is for RF Launchera}

A study was carried out to deternine the nuclear responses in two $R F$ launchers and the shlelding requireante to satiafy the design criterion of 2.5 mrea/h one dey after shutdown. The two leunchers for thle atudy are: INTOR beselline dealgn of $4 x 4$ erray of loops each protected by a Badome wich is cooled by a Paraday ahield braced to the Inside, end a ctack of ridge-loaded weveguides. Neutron fluences, nuclear heeting, gas production, and atomic dieplecesente were calculated to deteralne the operating conditlone and the expected life for the leunchera. Neutron fluxee at the back of the launchers were calculated to eatiane the bulk shield requirements.

Three-dimensional neutrontes celculetions have been performed for both launchera uaing the Monte-Carlo wethod. The HCAP code use used for the loop launcher dee 1 ga $10^{\text {cod w }}$ a continuoue energy repreeentation for the nuclear crose aections. The HORSt code vas enployed for the ridge neveguldes wth 67 witigroup coupled crose eection set. The zesulte from this study show that the number of Beo replacenents required during the IfroR $6.5 \mathrm{~m} \cdot \mathrm{y} / \mathrm{a}^{2}$ neutron fluence are 1 and $500 \mathrm{for}$ the ridge wavegulde and the loop launcher, to

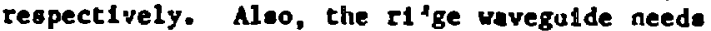
a 39-ca edditional shielding thickness to account for the gaps in the guide wodule while the loop launchers requite only $\bullet 21 \mathrm{ca}$.

\section{REACTOR SYSTEA CODES}

\section{A. Tokanak}

Heutrontco wdele for the tokunak reector eyeten code at rEDC rere developed, Inplemented, and used for the TrCX deefsn etudiee. The geonetricel codel used to renerate the wdel ls based on the TED deeiga configuration. Il Two hieldias optlons, eteel and 
tungaten, are Included in the uodel for th: Inboard section of the reector. Carbon or steel anor material for the inboard first wall sen be used uth both optlons. The steel type shield is used for the cutboard section. The codel can be uaed to calculace the shield dimensions to eatisfy opecific design criterla or calculate the nuclear responses for a opecific reactor configuration. The nuclear responses include nuclear heating in the IF collo, fast neutron fluence, dose in the Insulator matertal, atonte displacenents In the copper stabllizer, and dose equivalent In the reactor hall one day after shutdown. The shield compositions used to generate the model are based on the homogeneous optinization otudy parforaed for INTOR. 4,5 A paranetric atudy vas perforaed to generate the nuclear responses as a function of the shield thickness. The results fron this parametric study were used to generate numertcal correlations as a function of the shield thickness, operating tlwe, and neutron wall loading for the wodels.

\section{B. Tandea Mirror}

A blanket and shleld computational tool for the candew alrror reactors trade-off stum dles was developed. It consists of three modules for the central cell, the choke coll, and the end cell. The three wodules were Integrated in the Tandem Mirror Reactor Systea Code (TMRSC). 12

The central cell wodule (firat rall, blanket, and ahield) calculates dimensions, conposition, energy deposition in each reglon, tritlun breeding rativ for the breeding blanket option, radiation responses in the central cell coll, and the cost of each component. The total aterial thickness inside the central cell coll is based on Input design criterla or default values for the allowable nuclear reaponses in the colla. This module has several blanket optlons (L1 or 17L183Pb breeder; teel or carbon reflector; velfcooled for a liquid netal blanket; He or water coolant for nonbreeding blanket) and two shteld deaigna (aininue thickness concept and lou cost iteel) which can be specifled. The rodule can be used to aninize or axinize one or sore of seventeen blanket paraweters. Also, it can be used to perforn the analysis for apectfic design.

The choke coll wdule calculates the radiation responses in the choke coll (copper, superconductor, or hybrid design) and estiates the shield requirewente for the superconductor coll based on the allowable responses and the ohield cost.

The and cell oodule calculate the required shield thicknese Inolde the cee colls to satiafy the dealgn criteria, the radiation reaponces in the cee collo, and the blologital shield thicknese outolde the cae colla.

\section{REFERENCES}

1. S. YANG and i. GOHAR, "TPCX shlelding Optinization," Proc. of the 6th Toplcal Htg. on the Technology of Fueion Energy, San Prancieco, Ch, March 3-7, 1985.

2. V. D. LEE and $Y$. GOBAR, "Shield Deaign for Next-Generation Low Neutzon Fluence Superconducting Tokamaks,- Proc. of the 6th Toplcal Mtg. on the Technology of Pusion Energy. San Franciaco, CA, Mareh 3-7, 1985.

3. C. A. RLANAGAN, Tokanak Fusion Core Experiaent: Design Studies Based on Superconducting and Bybrid Toroldal pleld Colls, Design Overview,- Oak Rldge Natlonal Laboratory, ORNL/FEDC-84/3 (1984).

4. Y. GOHAR and H. A. ABDOU, "U.S. INTOR Radiation Shield Design,- Proc. of the 6th Int'1. Conf. on Radiation Shlelding, Tokyo, Japan (1983).

5. Y. GOHAR and M. A. ABDOJ, "INTOR Radiation Shielding for Personnel Access,- Minth Sympo- Iur on Engineering Probleas of Rusion Research, Chlcago, Il (1981).

6. H. ATTAYA, et al., "Blanket and shielding Conalderations for Advanced Tokanak Reactor Concepta, Uriversity of Haconsin, UWFDM-562 (1983).

7. S. YANG and Y. GOHAR, Hot Spote In the Inboard Section of the TPCX Toroldal Field Colle,- Proc, of the 6th Toplcal $\mathrm{Krg}$. on the Technology of Fusion Energy, San Prancleco, CA, March 3-7, 1985.

8. H. ATTAYA and Y. GOHAR, "HIG: MCAP Input Generator Por EPPI Magnet Geonetrlea," Proc. of the 6th Topical Mtg. on the Technology of Fusion Energy, San Francisco, Ch, Zarch 3-7, 1985.

9. P. T. SPAKPIMATO, P. A. IINA, Y. GOHAR, and R. STASKo, "A Comparison of All-Renote and Personnel Accees Maintenance Operations for INTOR,- Proc. of the 6th Topical Mtg. on the Tech. of Fueion Energy, San Francieco, CA. Harch 3-7, 1985.

10. H. E. SAWAR, "Huclear Envi roneent in the Array of Loopa ICRF Launcher Hodule of INTOR.U. of Wiscons $n$, UTFDA-575 (1984).

11. C. A. Fuhiagh, et al. "Püion Engineering Derlce Design Description," Dak Ridge Hatlonel Laboratory, ORkL/J7s-7948 (1981).

12. R. L. REID, et al., "Tanden mrror Reactor Syoten code (THRSC),- Pros. of the 6th Topical Mtg. on the Technology of Juelon Energy, San Francleco, CA, March 3-7, 1985. 